\title{
Pengaruh Pemberian Glutamin pada Kemampuan Fagositosis Makrofag terhadap Pseudomonas Aeruginosa
}

\author{
Daslina $^{1}$, Eryati Darwin², A.Aziz Djamal ${ }^{3}$
}

\begin{abstract}
Abstrak
Pseudomonas aeruginosa adalah bakteri penyebab infeksi terbanyak yang resisten terhadap antibiotik. Glutamin adalah asam amino yang terdapat dalam tubuh yang salah satu fungsinya dapat memodulasi imunitas tubuh. Tujuan penelitian ini adalah menentukan potensi glutamin dalam meningkatkan kemampuan sistem imun terhadap infeksi $P$. aeruginosa. Penelitian eksperimental dengan post test only control group design telah dilakukan terhadap 24 ekor mencit usia 6-8 minggu dengan berat $30 \mathrm{gr}$. Mencit dibagi ke dalam dua kelompok, yaitu kontrol $(\mathrm{K})$ dan perlakuan $(P)$ yang diberi glutamin dengan dosis $30 \mathrm{mg} / \mathrm{kg} /$ hari selama 14 hari. Isolasi makrofag peritoneum mencit dilakukan pada hari ke-15 dan dilakukan uji fagositosis menggunakan latex dan bakteri $P$. aeruginosa. Pengamatan dilakukan terhadap persentase makrofag aktif terhadap latex dan $P$. aeruginosa. Hasil pengamatan dan analisis statistik menggunakan metode $t$-test menunjukkan adanya perbedaan yang signifikan antara kontrol dan perlakuan $(p<0.05)$. Persentase makrofag aktif terhadap latex adalah 0,63 $\pm 0,058(K)$ dan 0,84 $\pm 0,04(P)$, sedangkan terhadap $P$. aeruginosa adalah $0,56 \pm 0,07(K)$ dan $0,80 \pm 0,03(P)$. Terlihat bahwa angka persentase fagositosis terhadap $P$. aeruginosa lebih kecil karena adanya kemampuan bakteri untuk menghadapi makrofag dibandingkan latex. Kesimpulan yang diperoleh dari penelitian ini adalah bahwa asam amino non-esensial glutamin memiliki pengaruh untuk meningkatkan kemampuan sistem imun tubuh.
\end{abstract}

Kata kunci: glutamin, fagositosis makrofag, Pseudomonas aeruginosa

\section{Abstract}

Pseudomonas aeruginosa is the most common cause of bacterial infections that are resistant to antibiotics. Glutamine is an amino acid in the body that able to modulate the body's immune function. The objective of this study was to determine the potential of glutamine in enhancing the ability of the immune system against infection of $P$. aeruginosa. Experimental research with post test only control group design was conducted on 24 male minutes 6-8 weeks of age weighing 30 grams. Mice were divided into two groups: control $(K)$ and treatment $(P)$ are given glutamine at a dose of $30 \mathrm{mg} / \mathrm{kg} /$ day for 14 days. Isolation of peritoneal macrophages of mice performed on day-15 and tested using latex and bacterial phagocytosis of $P$. aeruginosa. Observations were made of the percentage of activated macrophages toward latex and $P$. aeruginosa. The observation result and statistical analysis using $t$-test showed a significant difference between the control and treatment $(p<0.05)$. The percentage of active macrophages to latex was $0.63 \pm 0.058(K)$ and $0.84 \pm 0.04(P)$, while to $P$. aeruginosa is $0.56 \pm 0.07(K)$ and $0.80 \pm 0.03(P)$. That seein it percentage of phagocytosis against $P$. aeruginosa smaller than compared to latex. Because of the ability of bacteria to confront macrophages. The conclusion from this study is a non-essensial amino acid glutamine has the effect to increase the ability of the body's immune system.

Keywords: glutamin, immunity phagocytosis macrophage, Pseudomonas aeruginosa

Affiliasi penulis: 1. Prodi S2 Biomedik FK UNAND (Fakultas Kedokteran Universitas Andalas Padang), 2. Bagian Histologi FK UNAND, 3. Bagian Mikrobiologi FK UNAND

Korespondensi: Daslina, E-mail; linadaslina@yahoo.com, Telp: 081363175252

\section{PENDAHULUAN}

Pada saat ini infeksi bakteri semakin sulit untuk diobati, oleh karena sudah banyak yang resisten terhadap antibiotik. Bakteri patogen tetap mampu 
memperbanyak diri walaupun sudah diobati dengan pemberian antibiotik, maka keadaan tersebut dinamakan resistensi bakteri.Mekanisme terjadinya resistensi berlangsung selama bulanan sampai tahunan. Bakteri yang terkenal virulensinya dan mampu berkembang menjadi resisten diantaranya adalah Staphylococcus aureus, Enterococcus spp., Enterobacteriaceae, Pseudomonas aeruginosa dan Acinetobacter species. ${ }^{1}$

Saat ini sekitar $70 \%$ dari infeksi nosokomial mengalami resistensi terhadap sekurangnya satu jenis antibiotik yang sebelumnya efektif membunuh bakteri patogen.Pseudomonas aeruginosa merupakan salah satu bakteri yang menyebabkan peningkatan angka kesakitan, angka kematian dan biaya perawatan di rumah sakit. Menurut data Central for Disease Control and Prevention (CDC) pada tahun 2013, prevalensi infeksi oleh $P$. aeruginosa di Amerika Serikat adalah 6.700 kasus dan menyebabkan 440 kematian setiap tahunnya. $^{2}$

Di Rumah Sakit Jakarta dan sekitarnya ditemukan $12-19 \%$ bakteri $P$. aeruginosa dari hasil kultur bakteri kelompok Gram negatif dari tahun 20042010. Pseudomonas aeruginosa juga menjadi salah satu penyebab infeksi nosokomial terbanyak, terutama di unit perawatan intensif (ICU). ${ }^{3}$

Di ICU RS Fatmawati Indonesia, $P$. aeruginosa merupakan $26,5 \%$ bakteri yang dijumpai. Hasil penelitian yang dilakukan pada tahun 2003 di rumah sakit Dr. Moewardi Fakultas Kedokteran UNS Surakarta menunjukan bahwa organisme utama yang menyebabkan infeksi nosokomial meliputi $P$. aeruginosa (13\%), S. aureus (12\%), koagulasenegatif (10\%), Candida (10\%), Enterococci (9\%) dan Enterobacter (8\%). ${ }^{4}$

Berdasarkan hasil penelitian pada tahun 2010 di RSUP DR M. DJAMIL Padang menunjukkan bahwa bakteri $P$. aeruginosa merupakan salah satu bakteri yang banyak menginfeksi dan mengalami resistensi, dari penelitian terhadap pasien di bangsal Penyakit Dalam RSUP DR M. DJAMIL Padang didapatkan hasil bakteri yang paling sering menginfeksi adalah Klebsiella spp 29,9\%. Proteus spp 21,95\%, Pseudomonas aeruginosa 7,32\% dan E.coli 4,88\%. ${ }^{5}$

Pseudomonas aeruginosa merupakan bakteri oportunistik, yaitu memanfaatkan kerusakan pada mekanisme pertahanan inang untuk memulai suatu infeksi.Oleh karena itu bakteri ini sering menyerang pasien yang dirawat di ICU, karena pada umumnya pasien tersebut mengalami penurunan fungsi sistem imun atau immunocompromised. Pseudomonas aeruginosa berhubungan secara signifikan dengan prognosis buruk dari pasien yang sedang menjalani perawatan di rumah sakit, dimana kemungkinan terjadinya infeksi lain dapat meningkat sehingga menambah parah infeksi yang sudah ada. Infeksi $P$. aeruginosa menimbulkan berbagai penyakit di berbagai jaringan, diantaranya pada sistem sirkulasi darah saluran nafas, saluran kemih, saluran gastrointestinal dan kulit. $^{6}$

Pseudomonas aeruginosa merupakan spesies dari genus Pseudomonas, yang sering ditemukan sebagai bakteri saprofit normal pada usus dan kulit manusia. Pseudomonas aeruginosa memiliki bentuk batang dengan ukuran sekitar 0,6 x $2 \mu \mathrm{m}$. Bakteri ini terlihat sebagai bakteri tunggal, berpasangan, dan terkadang membentuk rantai yang pendek dan merupakan bakteri gram negatif. Bakteri ini bersifat aerob, katalase positif, oksidase positif, tidak mampu memfermentasi tetapi dapat mengoksidasi glukosa/karbohidrat lain dan tidak berspora, tidak mempunyai selubung dan mempunyai flagel monotrika sehingga selalu bergerak. Pseudomonas aeruginosa adalah patogen utama dari kelompok pseudomonas yang bersifat invasif dan toksigenik serta yang paling sering didapatkan dari spesimen klinis. ${ }^{7}$

Penatalaksanaan $P$. aeruginosa menggunakan antibiotik masih menjadi pilihan yang paling banyak digunakan sampai saat ini. Pengendalian menggunakan antibiotik sering mengalami kendala akibat respon yang lambat terhadap terapi yang diberikan dan sering timbulnya resistensi pada bakteri $P$. aeruginosa, banyak penelitian yang melaporkan bahwa saat ini $P$. aeruginosa mengalami resistensi yang tinggi terhadap berbagai jenis antibiotik. Metode selain penggunaan antibiotik perlu dikembangkan, salah satu cara yang efektif untuk mengendalikan infeksi yang disebabkan oleh $P$. aeruginosa adalah dengan meningkatkan daya tahan tubuh. ${ }^{8}$

Glutamin, adalah suatu bahan asam amino non-esensial paling berlimpah di otot dan plasma tubuh manusia. Asam amino ini memiliki peran 
penting dalam sintesis protein, mengawali proses yang mengatur berbagai proses metabolisme energi dan menjadi prekursor untuk substrat yang penting bagi tubuh, glutamin juga berguna untuk meningkatkan proliferasi dan meningkatkan fungsi dari sel makrofag. Proliferasi makrofag yang terjadi di sumsum tulang dapat meningkat karena glutamin akan menjadi prekursor arginin. Arginin dapat meningkatkan proliferasi dan fungsi makrofag dalam sumsum tulang. Asam amino ini mempunyai peran penting terhadap metabolisme sel makrofag yang terlibat dalam proses innate immunity. Sel imunokompeten tersebut mampu memfagositosis patogen, membunuh fungi, dan menghasilkan nitric oxide (NO), interleukin, tumor necrosis factor $\alpha$ (TNF $\alpha)$ dan reactive oxygen species (ROS). Glutamin mampu menstimulasi makrofag untuk meningkatkan sekresi arginase dan menyediakan Nicotinamide Adenine Dinucleotida Phosphate (NADP) sehingga meningkatkan sekresi NO oleh makrofag.Nitric oxide berperan penting dalam mekanisme bacterial killing. ${ }^{9}$

Berdasarkan uraian diatas, maka dilakukanlah penelitian eksperimental ini untuk melihat potensi glutamin terhadap peningkatan kemampuan fagositosis makrofag pada $P$. aeruginosa. Apabila pemberian glutamin terbukti meningkatkan respon imunitas tubuh, maka pemberian glutamin dapat dikembangkan lebih lanjut sebagai suplementasi dalam menunjang pengobatan infeksi yang disebabkan oleh $P$. aeruginosa.

\section{METODE}

Jenis penelitian yang digunakan adalah eksperimental yang menggunakan desain penelitian post test only control group, yaitu rancangan yang digunakan untuk mengukur pengaruh perlakuan pada kelompok eksperimen terebut dengan cara membandingkannya terhadap kelompok kontrol. ${ }^{10}$ Penelitian dilakukan terhadap 24 ekor mencit usia 6-8 minggu dengan berat $30 \mathrm{gr}$. Mencit dibagi ke dalam dua kelompok, yaitu kontrol (K) dan perlakuan (P) yang diberi glutamin dengan dosis $30 \mathrm{mg} / \mathrm{kg} / \mathrm{hari}$ selama 14 hari.
HASIL

Penelitian dilaksanakan mulai dari Juli sampai Agustus 2014 di Laboratorium Farmasi Universitas Andalas untuk pemeliharaan dan perlakuan hewan coba dan Laboratorium Mikrobiologi RSUP DR. M. DJAMIL Padang sebagai tempat melakukan uji aktifitas fagositosis makrofag dari hewan coba.

\section{Jumlah Makrofag Peritoneum}

Hasil penghitungan jumlah makrofag yang diambil dari cairan peritoneum per $\mathrm{ml}$ menggunakan kamar hitung hemositometer neubauer.

Tabel 1. Jumlah makrofag peritoneum

\begin{tabular}{lcll}
\hline Kelompok & $\mathbf{n}$ & $\begin{array}{l}\text { Rerata } \pm \\
\text { SD }\left(\times 10^{7} / \mathbf{m l}\right)\end{array}$ & $\mathbf{P}$ \\
\hline Kontrol & 12 & $3,40 \pm 0,45$ & 0.000 \\
Perlakuan & 12 & $4,88 \pm 0,64$ &
\end{tabular}

Berdasarkan Tabel 1 didapatkan rerata jumlah makrofag peritoneal kelompok perlakuan lebih tinggi dibandingkan dengan kelompok kontrol $(4,88 \pm 0,64$ : $3,40 \pm 0,45$; secara statistik terdapat perbedaan yang signifikan $\mathrm{P}<0,05)$.

\section{Aktifitas Fagositosis Makrofag}

Uji fagositosis menggunakan lateks dilakukan setelah jumlah makrofag peritoneum masing-masing kelompok hewan coba diketahui.

Tabel 2. Aktifitas fagositosis makrofag

\begin{tabular}{llll}
\hline Kelompok & $\mathbf{n}$ & Rerata \pm SD & $\mathbf{P}$ \\
\hline Kontrol & 12 & $0,63 \pm 0,05$ & \\
Perlakuan & 12 & $0,84 \pm 0,04$ & \\
\hline
\end{tabular}

Berdasarkan Tabel 2 didapatkan aktifitas fagositosis makrofag kelompok perlakuan lebih tinggi dibandingkan dengan kelompok kontrol $(0,84 \pm 0,04$ : $0,63 \pm 0,05$; secara statistik terdapat perbedaan yang signifikan $\mathrm{P}<0,05)$. 
3. Aktifitas Fagositosis Makrofag terhadap bakteri $P$. aeruginosa

Dari setiap sampel diambil makrofag dengan konsentrasi $1 \times 10^{6}$ dan ditambahkan suspensi Pseudomonas aeruginosa dengan konsentrasi 2,5 $\times 10^{7}$ kemudian dilihat dibawah mikroskop dan dihitung persentasi makrofag yang aktif memfagositosis dari 200 makrofag yang terlihat.

Tabel 3. Hasil analisis aktifitas fagositosis makrofag terhadap $P$. aeruginosa

\begin{tabular}{lccl}
\hline Kelompok & $\mathbf{N}$ & Rerata \pm SD & $\mathbf{p}$ \\
\hline Kontrol & 12 & $0,56 \pm 0,07$ & \\
Perlakuan & 12 & $0,80 \pm 0,03$ & 0.000 \\
\hline
\end{tabular}

Berdasarkan Tabel 3, aktifitas fagositosis makrofag terhadap Pseudomonas aeruginosa kelompok perlakuan lebih tinggi dibandingkan dengan kelompok kontrol $(0,80 \pm 0,03$ : 0,56 $\pm 0,07$; secara statistik terdapat perbedaan yang signifikan $P<0,05)$.

\section{PEMBAHASAN}

Penelitian ini memiliki tujuan untuk membuktikan bahwa pemberian glutamin dengan dosis $30 \mathrm{mg} / \mathrm{kgBB} /$ hari dapat meningkatkan jumlah makrofag peritoneum serta aktifitas fagositosis mencit putih betina terhadap bakteri $P$. aeruginosa. Dosis glutamin digunakan berdasarkan penelitian yang dilakukan oleh Rahmi, yaitu pemberian glutamin dengan dosis $30 \mathrm{mg} / \mathrm{kgBB} /$ hari merupakan dosis yang paling efektif untuk meningkatkan jumlah dan aktivitas makrofag yang bermakna. ${ }^{11}$ Sedangkan dasar waktu pemberian glutamin yaitu sesuai penelitian yang dilakukan oleh Rogero. Bahwa pemberian glutamin selama 14 hari sudah mampu meningkatkan jumlah dan fungsi makrofag peritoneum. ${ }^{12}$

\section{Jumlah Makrofag Peritoneum Mencit}

Penelitian yang telah dilakukan memberikan hasil yang menunjukkan adanya pengaruh pemberian glutamin terhadap jumlah makrofag mencit. Perbedaan jumlah makrofag mencit kontrol dengan mencit perlakuan menunjukkan hasil yang signifkan $(P<0,05)$.
Peningkatan proliferasi makrofag ini dapat terjadi karena asam amino glutamin mempunyai peran penting terhadap metabolisme sel makrofag yang terlibat dalam proses innate immunity. Sel imunokompeten tersebut mampu memfagositosis patogen, membunuh fungi dan menghasilkan nitric oxide (NO), interleukin, tumor necrosis factor $\alpha$ (TNFa) dan reactive oxygen species (ROS). Glutamin mampu menstimulasi makrofag untuk meningkatkan sekresi arginase dan menyediakan Nicotinamide Adenine Dinucleotida Phosphate (NADP) sehingga meningkatkan sekresi NO oleh makrofag. Nitric oxide berperan penting dalam mekanisme bacterial killing. ${ }^{9}$

Glutamin memiliki peran sebagai sumber energi sekaligus prekursor nukleotida bagi proliferasi sel makrofag. Pembentukan energi dari glutamin terdiri dari beberapa tahap, dimulai dengan proses deaminasi (hidrolisis) glutamin oleh enzim glutaminase sehingga membentuk glutamat. Kemudian glutamat mengalami proses deaminasi (hidrolisis) membentuk a-ketoglutarat. Lalu $\alpha$-ketoglutarat memasuki siklus Krebs dan menghasilkan energi. Asam amino tersebut dapat langsung menghasilkan energi atau diubah menjadi glukosa melalui proses glukoneogenesis, yang pada akhirnya juga menghasilkan energi yang diperlukan untuk proliferasi sel makrofag. Sehingga dapat disimpulkan bahwa glutamin berguna untuk meningkatkan proliferasi dan meningkatkan fungsi dari sel makrofag. ${ }^{13}$

\section{Aktifitas Fagositosis Makrofag}

Hasil penilaian uji fagositosis makrofag terhadap lateks antara kelompok kontrol dengan kelompok perlakuan menunjukkan adanya perbedaan yang signifkan $(P<0,05)$, hal ini membuktikan adanya pengaruh glutamin terhadap peningkatan kemampuan fagositosis makrofag.

Glutamin dapat meningkatkan persediaan NADPH yang dibutuhkan untuk setiap reaksi enzimatik pada proses fagositosis. Glutamin juga dapat menjadi prekursor arginin melalui proses konversi glutamin menjadi sitrulin yang kemudian dirubah menjadi arginin. Reaksi arginin dengan NADPH meningkatkan sekresi nitric oxide (NO) oleh makrofag. Arginin dirubah menjadi NO oleh Nitric Oxide Synthetase (iNOS) yang dimiliki makrofag. Oleh karena itu 
kelompok perlakuan yang diberi glutamin memiliki kemampuan fagositosis yang lebih tinggi dibandingkan kelompok kontrol yang tidak diberi glutamine. ${ }^{14}$

\section{Aktifitas Fagositosis Makrofag Peritoneum terhadap} $P$. aeruginosa

Hasil foto mikroskop, memperlihatkan bahwa pada kelompok kontrol memiliki kemampuan fagositosis yang lemah dibandingkan dengan kelompok perlakuan. Terdapat perbedaan yang signifikan $(\mathrm{P}<0,05)$ dari perbedaan jumlah makrofag yang aktif memfagositosis latexs antara dua kelompok. Pada kelompok perlakuan menunjukkan kemampuan fagositosis yang lebih kuat, dilihat dari jumlah makrofag yang aktif memfagositosis bakteri $P$. aeruginosa lebih banyak dari pada kelompok control.

Beberapa penelitian ada yang menunjukan bahwa bakteri $P$. aeruginosa merupakan salah satu bakteri yang dapat menginvasi sel inang dengan cara intraseluler. Sistem imun tubuh untuk menghadapi bakteri intraseluler ini tidak membutuhkan antibodi, tetapi melalui aktivasi makrofag, natural killer cells (NK), antigen-specific cytotoxic T-lymphocytes, dan sekresi sitokin. ${ }^{15}$

Pengaruh peningkatan aktifitas fagositosis makrofag yang diperankan oleh glutamin adalah karena terjadinya peningkatkan produksi sitokin, NADPH, dan sebagai prekursor arginin.Sitokin merupakan unsur penting untuk aktivasi makrofag, sedangkan NADPH digunakan untuk proliferasi sel, sintesis hidrogen peroksida (H2O2), anion superoksida (O-), dan sintesis NO dari arginin. Semua komponen diatas dapat meningkat dengan adanya suplemen glutamine. Asam amino glutamin mampu dihasilkan secara endogen oleh tubuh manusia, namun dalam beberapa kondisi tertentu, misalnya pada stres atau infeksi, tubuh tidak mampu memproduksi glutamin dengan jumlah yang cukup sehingga tubuh membutuhkan asupan glutamin dari luar. ${ }^{16}$ Beberapa sumber makanan yang banyak mengandung glutamin antara lain adalah kacangkacangan, ayam, telur, daging babi, dan terbanyak pada daging sapi, pemberian suplementasi glutamin dari luar akan mencukupi sebagian kebutuhan glutamin. ${ }^{17}$
Meningkatnya jumlah glutamin dalam tubuh, maka sumber nitrogen untuk sintesis purin dan pirimidin akan meningkat juga,dalam biosintesis purin, nitrogen amida dari glutamin berperan dalam konversi inosin monofosfat (IMP) menjadi adenosine monofosfat (AMP) dan guanosin monofosfat (GMP). Pada lintasan biosintesis pirimidin, glutamin berperan dalam pembentukan carbamoyl phospatase, dan dengan menyumbangkan gugus amin mengubah uridin trifosfat (UTP) menjadi cytidine trifosfat (CTP).Purin dan pirimidin merupakan penyusun nukleotida, yang menjadi komponen vital dalam proliferasi makrofag. ${ }^{18}$

Ikatan antara makrofag dengan mikroba terjadi pada saat makrofag memanjangkan plasmanya. Ikatan ini dimediasi oleh beragam reseptor antibodi, lipopolisakarida (LPS) dan komplemen reseptor. Makrofag yang distimulasi oleh LPS mensekresikan berbagai macam sitokin seperti TNF- $\alpha$, IL-6, IL-8 dan IL-1 $\beta$ yang dapat meningkatkan respon imun dan inflamasi seperti merekrut dan mengaktivasi sel imun termasuk makrofag yang lain, selain itu juga meningkatkan produksi antibodi yang membantu dalam pengenalan patogen. Penelitian yang dilakukan glutamin dapat meningkatkan jumlah proliferasi makrofag peritoneum, sintesis $\mathrm{NO}$, dan peningkatan adhesi bakteri oleh makrofag. ${ }^{12}$

Reseptor akan mengirimkan sinyal yang dapat mengaktifkan berbagai enzim di dalam fagolisosom pada saat $P$. aeruginosa dilengkapi oleh reseptor fagosit dan ditelan, salah satunya adalah nitric oxide synthetase yang memiliki fungsi untuk mengonversi arginin menjadi nitric oxide (NO) sebagai substansi mikrobisidal. ${ }^{12}$

Glutamin termasuk salah satu prekursor dari arginin sehingga adanya suplemen glutamin mampu meningkatkan kadar arginin dalam darah. Dengan demikian hal tersebut dapat meningkatkan produksi NO yang berpengaruh pada peningkatan aktivitas fagositosis makrofag terhadap $P$. aeruginosa. ${ }^{19}$

Penjelasan lain yang mendasari pengaruh glutamin dalam meningkatkan aktifitas fagositosis makrofag adalah kemampuan asam amino ini dalam menghasilkan NADPH pada saat dimetabolisme, NADPH dirubah menjadi NADP+ oleh enzin NADPH 
oksidase dan menstimulus perubahan $\mathrm{O} 2$ menjadi O(anion superoksida) yang kemudian dapat bereaksi spontan menjadi $\mathrm{H} 2 \mathrm{O} 2$ sebagai unsur bakterisidal yang kuat. ${ }^{20}$

Hasil penelitian yang telah dilaksanakan ini dimana ditemukan adanya peningkatan jumlah dan aktivitas fagositosis makrofag peritoneum serta didukung oleh penelitian sebelumnya, bahwa pemberian glutamin secara in vivo mampu meningkatkan aktivitas makrofag terhadap Mycobacterium bovis, kemudian dilengkapi dengan adanya data bahwa glutamin dapat meningkatkan produksi sitokin, NADPH, dan sebagai prekursor arginine.

Pemberian glutamin dengan dosis 30 $\mathrm{mg} / \mathrm{kg} /$ hari selama 14 hari mampu menigkatkan jumlah dan aktifitas fagositosis makrofag terhadap bakteri $P$. aeruginosa. Hal ini menjadi bukti bahwa hipotesis yang telah disusun sebelumnya adalah benar.

Sistim imunitas dapat ditingkatkan dengan mengkonsumsi makanan yang memiliki kandungan glutamin tinggi seperti daging sapi mampu meningkatkan sistem imunitas. Makanan dari daging sapi atau sumber glutamin tinggi lainnya dapat diproduksi menjadi suplemen makanan untuk meningkatkan keberhasilan pengobatan antibiotik terhadap infeksi khususnya infeksi $P$. aeruginosa.

\section{KESIMPULAN}

Pemberian glutamin dengan dosis 30 $\mathrm{mg} / \mathrm{kg} / \mathrm{hari}$ (0.9 mg/30gram BB mencit) mampu meningkatkan jumlah makrofag peritoneum mencit.

Pemberian glutamin dengan dosis 30 $\mathrm{mg} / \mathrm{kg} / \mathrm{hari} \quad(0.9 \mathrm{mg} / 30 \mathrm{gram}$ BB mencit) mampu meningkatkan aktifitas fagositosis makrofag peritoneum mencit putih betina terhadap lateks.

Pemberian glutamin dengan dosis 30 $\mathrm{mg} / \mathrm{kg} / \mathrm{hari}$ (0.9 mg/30gram BB mencit) mampu meningkatkan aktifitas fagositosis makrofag peritoneum mencit putih betina terhadap bakteri Pseudomonas aeruginosa.

\section{UCAPAN TERIMA KASIH}

Terima kasih kepada Staf Bagian Laboratorium Mikrobiologi RSUP DR. M. Djamil Padang yang telah membantu dalam menyelesaikan penelitian ini.

\section{DAFTAR PUSTAKA}

1. Cai $G$, Jing $Y$, Zhaocai $Z$, Yihua $Y$. Immunomodulatory effects of glutamine-enriched nutritional support in elderly patients with severe sepsis: a prospective, randomized, controlled study. Journal of Organ Dysfunction. 2008;4:31-7.

2. CDC Contributor. Antibiotic resistance threats in the United States. U.S Centers for Disease Control and Prevention. 2013

3. Moehario, Lucky H, Teguh S, Hartono E, Wardoyo $\mathrm{H}$, Enty T. Trend of antibiotics susceptibility of multidrugs resistance Pseudomonas aeruginosa in Jakarta and surrounding areas from 2004 to 2010. African Journal of Microbiology Research. 2012;6(9):2222-9.

4. Sulistiyaningsih. Uji kepekaan beberapa sediaan antiseptik terhadap bakteri Pseudomonas aeruginosa dan Pseudomonas aeruginosa multi resisten (PAMR) (diunduh 25 April 2014). Tersedia dari: URL: HYPERLINK http://www.pustaka. unpad.ac.id/.

5. Lestari L, Ayu, Resta, Lita, Wulan, et al. Profil Pseudomonas Aureginosa yang mengalami resisten antibiotik di RSUP DR.M Djamil Padang. (diunduh 8 April 2014). Tersedia dari: URL: HYPERLINK http//www.unand.ac.id

6. Ravi D, Suresh P, Sankalp. Epidemiology of intensive care unit infections and impact of infectious disease consultants in managing resistant infections. American Journal of Infectious Diseases. 2013;(9):30-3.

7. Jawetz M, Adelberg's G, Brooks F, Janet S, Butel, Stefhen, et al. Medical microbiology. Edisi ke-25. United States of America: McGraw-Hill Companies, Inc: 2010.

8. Winn W, Lipincott W, Koneman, Philadelphia, et al. The Nonfermentative gram-negative bacilli. Dalam: Koneman's Color Atlas and Texbook of Diagnostic Microbiology. Edisi ke-6. Philadelphia: Lipincott Willian \& Wilkins; 2006.

9. Briassouli E, Briassoulis G. Glutamine randomized studies in early life: the unsolved riddle of experimental and clinical studies. Hindawi Publishing Corporation Clinical and Developmental Immunology. 2012;17:28-30. 
10. Sastroamoro S, Ismail S. Dasar-dasar metodologi penelitian klinis. Edisi Ke-2. Jakarta: 2002.

11. Rahmi AP. Pengaruh pemberian glutamin terhadap jumlah limfosit Rattus novergicus strain Wistar dengan diet rendah protein. Malang:Program Studi Pendidikan Dokter Universitas Brawijaya; 2009.

12. Rogero T, Vinolo C, Barolli, et al. Dietary glutamine supplementation increases the activity of peritoneal macrophages and hemopoiesis in early-weaned mice inoculated with, 2012.

13. Andrews FJ, Griffiths RD. Glutamine: essential for immune nutrition in the critically III. 2002;51:3-8.

14. Wallace C, Keast D. Glutamine and macrophage function. Metabolism. 1992:1016-20.

15. Christian, William L. Pseudomonas aeruginosa new evidence for intracellular persistence. Trends in Microbiology. 2009:59-5.

16. Seebohar B. Glutamine: essential nonessential amino acid. endurance reaserach board (diunduh 19 April 2014). Tersedia dari: URL: HYPERLINK http://www.trifuel.com/

17. Bambang, Natura K OS. BPOM RI. 2008;3-9.

18. Rodwell, Victor W. metabolisme nukleotida purin dan pirimidin. Biokimia HarperTerjemahan. Edisi ke-25. Jakarta: EGC; 2003. hlm.56-60.

19. Abbas AK, Lichtman AH, Pillai S. Cellular dan molecular immunology. Edisi ke-6. Philadelphia: WB Saunders Company; 2010.

20. Newsholme P. Why is L-glutamine metabolism important to cells of the immune system in health, postinjury, surgery or infection?. Journal of Nutrition. 2001: 344-50. 